\title{
PIMAS
}

Jurnal Pengabdian Masyarakat

Homepage: http://ejournal.uhb.ac.id/index.php/PIMAS

\section{Pemenuhan Pangan Lokal Sebagai Kebutuhan Gizi Bayi Dan Balita Umur 6 -24 Bulan Di Kabupaten Banyumas}

\author{
Fauziah Hanum Nur Adriyani ${ }^{1},{ }^{*}$ Arlyana Himanti ${ }^{2}$, Rosi Kurnia Sugiharti ${ }^{3}$ \\ 1,2,3 Prodi Kebidanan Fakultas Kesehatan Universitas Harapan Baangsa \\ ${ }^{1}$ fauziahhanum@uhb.ac.id*; ${ }^{2}$ arlyana.shb0610@gmail.com; ${ }^{3}$ rosikurnia@uhb.ac.id
}

Artikel History:

Received: 09-12-2021 / Received in revised form: 20-01-2022 / Accepted: 28-01-2022

\begin{abstract}
One of the risk factors for stunting is lack of nutritional intake in the long term. Toddlers with poor nutritional status have a low immune system which can make them susceptible to infectious diseases. The macro nutrition improvement program is directed at reducing macro nutrition problems, which primarily address the problem of protein energy deficiency. The processing and development of local food ingredients as a source of need to overcome the stunting problem is still not widely carried out by mothers in the Banyumas Regency area.Integrated service post cadres (posyandu) and Family Welfare Development cadres (PKK) are major milestones in public health, especially infants and toddlers through their activities in mobilizing their citizens to utilize local food. So that in this activity the researchers held training for cadres, PKK mothers and mothers of babies and toddlers 6 24 months in all areas of Banyumas Regency in local food processing as an effort to handle and prevent nutritional problems in Banyumas Regency.Based on observations that have been made, out of all partners, around $80 \%$ of partners are skilled, and independent in implementing the processing of complementary foods made from local breast milk.
\end{abstract}

Keywords : Local food, training, cadres, Infants and Toddlers

\begin{abstract}
ABSTRAK
Salah satu faktor risiko kejadian Stunting kurangnya asupan gizi dalam jangka waktu yang lama. Balita dengan status gizi yang kurang mempunyai sistem imun yang rendah yang dapat membuat balita mudah terkena penyakit infeksi. Program perbaikan gizi makro diarahkan untuk menurunkan masalah gizi makro yang utamanya mengatasi masalah kurang energi protein. Pengolahan dan pengembangan bahan pangan lokal sebagai sumber kebutuhan untuk menanggulangi permasalah stunting masih belum banyak dilakukan oleh ibu-ibu di area Kabupaten Banyumas.Kader Pos pelayanan terpadu (posyandu) dan kader Pembinaan Kesejahteraan Keluarga (PKK) merupakan tonggak utama dalam kesehatan masyarakat khususnya bayi dan balita lewat kegiatannya dalam mengerahkan warganya untuk memanfaatkan pangan lokal. Sehingga pada kegiatan ini peneliti mengadakan pelatihan bagi kader,ibu PKK dan ibu bayi dan balita $6-24$ bulan di seluruh wilayah Kabupaten Banyumas dalam pengolahan pangan lokal sebagai upaya penanganan dan pencegahan permasalahan gizi di Kabupaten Banyumas. Berdasarkan observasi yang telah dilakukan, dari keseluruhan mitra sekitar $80 \%$ mitra mampu terampil, dan mandiri dalam menerapkan pengolahan makanan pendamping ASI berbahan dasar lokal.
\end{abstract}

Kata kunci : Pangan lokal, pelatihan, kader,Bayi dan Balita

\section{PENDAhUluan}

Stunting merupakan keadaan tubuh yang pendek menurut umur hingga melampaui defisit -2 SB dibawah median standar panjang atau tinggi badan menurut umur (Kemenkes 2018). Telah diketahui bahwa semua masalah anak pendek, bermula pada proses tumbuh kembang janin dalam kandungan

*Corresponding author. Tel.: +62821-000-000

Email:author@institute@ac.id 
sampai usia 2 tahun. Apabila dihitung dari sejak hari pertama kehamilan, kelahiran bayi sampai anak usia 2 tahun merupakan periode 1000 hari pertama kehidupan manusia, disebut sebagai window opportunity. Pada tahun 2017, lebih dari setengah balita stunting di dunia berasal dari Asia (55\%) sedangkan lebih dari sepertiganya (39\%) tinggal di Afrika. Dari 83,6 juta balita stunting di Asia, proporsi terbanyak berasal dari Asia Selatan (58,7\%) dan proporsi paling sedikit di Asia Tengah $(0,9 \%)$ (Report, 2020). Prevalensi stunting menurut Rikesdas 2018 angka nasional sebesar 30,8\% yang berarti adanya penurunan yang tidak terlampau signifikan dari tahun 2013 (37,2\%) (Kemenkes, 2018). Indonesia masuk dalam ranking ke 5 terbesar dengan prevalensi stunting di seluruh dunia. Angka stunting di Indonesia diharapkan dapat tercapai target dalam upaya Sustainable Development Goals (SDGs) pada tahun 2025 yaitu penurunan angka stunting hingga 40\% (Kemenkes 2018, n.d.).

Prevalensi stunting di Provinsi Jawa Tengah yaitu sebesar 32,6\% angka ini melebihi prevalensi stunting di Indonesia (Dinas Kesehatan Provinsi Jawa Tengah, 2019). Salah satu faktor risiko kejadian Stunting kurangnya asupan gizi dalam jangka waktu yang lama, sehingga dapat terjadi perlambatan pertumbuhan dan berpengaruh terhadap status gizi (Sudaryati et al., 2017). Penyakit infeksi dapat mengakibatkan berat badan turun secara akut dan berpengaruh pada status gizi balita bila terjadi dalam jangka waktu yang lama. Balita dengan status gizi yang kurang mempunyai sistem imun yang rendah yang dapat membuat balita mudah terkena penyakit infeksi (Hendricks, 2001). Kondisi sosial ekonomi dan sanitasi tempat tinggal juga berkaitan dengan terjadinya stunting. Kondisi ekonomi erat kaitannya dengan kemampuan dalam memenuhi asupan yang bergizi dan pelayanan kesehatan untuk bayi dan balita (Mohammed et al., 2019).

Program perbaikan gizi makro diarahkan untuk menurunkan masalah gizi makro yang utamanya mengatasi masalah kurang energi protein terutama di daerah miskin baik di pedesaan maupun di perkotaan dengan meningkatkan keadaan gizi keluarga, meningkatkan partisipasi masyarakat, meningkatkan kualitas pelayanan gizi baik di Puskesmas maupun di posyandu, dan meningkatkan konsumsi energi dan protein pada balita gizi buruk (BAPENAS, 2011). Evaluasi juga dilaksanakan dalam pelaksanaan program perbaikan gizi makro, yaitu dimulai dari evaluasi input, proses, output dan impak dengan tujuan untuk menilai persiapan, pelaksanaan, pencapaian target dan prevalensi status gizi pada sasaran (Kemenkes, 2019). Nutrisi yang diperoleh sejak bayi lahir tentunya sangat berpengaruh terhadap pertumbuhannya termasuk risiko terjadinya stunting. Tidak terlaksananya inisiasi menyusu dini (IMD), gagalnya pemberian air susu ibu (ASI) eksklusif, dan proses penyapihan dini dapat menjadi salah satu faktor terjadinya stunting. Sedangkan dari sisi pemberian makanan pendamping ASI (MP ASI) hal yang perlu diperhatikan adalah kuantitas, kualitas, dan keamanan pangan yang diberikan (Sudaryati et al., 2017). Pada tahun 2017, Secara nasional, cakupan bayi mendapat ASI eksklusif pada tahun 2017 sebesar 61,33\%. Provinsi Jawa Tengah masih berada di bawah cakupan yaitu sebesar $54,40 \%$. Asupan zat gizi pada balita sangat penting dalam mendukung pertumbuhan sesuai dengan grafik pertumbuhannya agar tidak terjadi gagal tumbuh (growth faltering) yang dapat menyebabkan stunting (Dinas Kesehatan Provinsi Jawa Tengah, 2019).

Indikator paling sederhana untuk menentukan normal atau tidaknya pertumbuhan balita yakni dengan melihat kondisi fisik atau yang disebut sebagai status gizi dengan metode antropometri. Parameter yang paling mudah dan sesuai untuk mengukur status gizi balita adalah berat badan, tinggi badan atau panjang badan dan umur, dengan indeks yang digunakan adalah BB/U, BB/TB dan TB/ U (Kemenkes RI, 2011). Intervensi yang dilakukan untuk menanggulangi masalah gizi pada bayi dan balita diantaranya yaitu Inisiasi Menyusu Dini (IMD) saat bayi baru lahir, dilanjutkan dengan pemberian ASI Eksklusif selama 6 bulan tanpa tambahan makanan apapun kecuali obat, dilanjutkan pemberian ASI selama 2 tahun dengan ditambah Makanan Pendamping ASI yang berkualitas (MP-ASI) (Aryastami, 2017).

World Health Organization (WHO) dalam Resolusi World Health Assembly (WHA) nomor 55.25 tahun 2002 tentang Global Strategy of Infant and Young Child Feeding melaporkan bahwa 60\% kematian balita langsung maupun tidak langsung disebabkan oleh kurang gizi dan 2/3 dari kematian tersebut terkait dengan praktik pemberian makan yang kurang tepat pada bayi dan anak (WHO, 2003) . Pemberian makan yang terlalu dini dan tidak tepat mengakibatkan banyak anak yang menderita kurang gizi (BPS, 2020). Untuk itu perlu dilakukan pemantauan pertumbuhan sejak lahir secara rutin dan berkesinambungan. Fenomena "gagal tumbuh" atau growth faltering pada anak Indonesia mulai terjadi 
pada usia 4-6 bulan ketika bayi diberi makanan selain ASI dan terus memburuk hingga usia 18-24 bulan. Hasil Riskesdas 2018 menunjukkan 19,6\% balita di Indonesia yang menderita gizi kurang (BB/U <-2 Z-Score) dan 37,2\% termasuk kategori pendek (TB/U <- 2 ZScore) (Report, 2020).

Makanan Pendamping Air Susu Ibu (MP-ASI) mulai diberikan sejak bayi berumur 6 bulan bertujuan untuk memenuhi kebutuhan gizi bayi dan anak selain dari ASI. MP-ASI yang diberikan dapat berupa makanan berbasis pangan lokal. Pemberian MP-ASI berbasis pangan lokal dimaksudkan agar keluarga dapat menyiapkan MP-ASI yang sehat dan bergizi seimbang bagi bayi dan anak 6-24 bulan di rumah tangga sekaligus sebagai media penyuluhan. Fenomena terjadi pada tenaga kader sebagai ujung tombak pelaksanaan kegiatan posyandu yang berfungsi untuk mengontrol status gizi bayi dan balita, bahwasanya banyak kader yang belum mengetahui pengolahan variasi produk lokal untuk makanan pendamping ASI, sehingga berdasarkan kegiatan pemberdayaan masyarakat yang dilaksanakan oleh Amar (2019) di Kabupaten Lebak memberikan penyuluhan kepada kader tentang pembuatan MP-ASI lokal Bahan Makanan Campuran (BMC) untuk menigkatkan status gizi balita stunting (Amar \& Nasrullah, 2020). Setiap keluarga yang mempunyai bayi dan anak usia 6-24 bulan hendaknya mempunyai pengetahuan tentang Pemberian Makanan Bayi dan Anak, agar mampu memberikan ASI ekslusif dan menyiapkan MP-ASI yang sesuai di masing-masing keluarga.

Pendampingan oleh orang yang terdekat dalam hal ini termasuk kader posyandu sangat penting. Untuk itu kader posyandu perlu dilatih agar mempunyai pengetahuan tentang ASI ekslusif dan MP-ASI. Hal serupa juga dilakukan oleh Margareta (2019), bahwasanya Kader dan Ibu terutama wajib mengetahui tentang pemenuhan gizi seimbang pada bayi dan balitanya sehingga terhindar dari masalah stunting (Margaretta, 2019). Peranan tenaga kader posyandu terampil sangat besar terhadap keberhasilan Pemberian makanan bayi (PMB), peningkatan pemberdayaan ibu, peningkatan dukungan anggota keluarga serta peningkatan kualitas makanan bayi dan anak yang akan meningkatkan status gizi balita Masalah utama yang dihadapi kader gizi adalah keterbatasan pengetahuan pangan bergizi seimbang dan hubungannya dengan kurang gizi pada balita. Selain itu, masalah yang prioritas juga adalah keterbatasan kemampuan keluarga rawan gizi terkait aspek pengetahuan gizi dan akses pangan bergizi seimbang. Masalah lainnya yang disetujui adalah rendahnya keterampilan mengolah makanan bergizi seimbang sebagi makanan pendamping ASI (MP-ASI) dan makanan Tambahan Balita. Oleh karena itu perlu dilakukan pelatihan pembuatan makanan tambahan pada bayi dan balita guna peningkatan pengetahuan dan ketrampilan

\section{METODE PELAKSANAAN KEGIATAN}

\subsection{Tahap Kegiatan}

Tahap Persiapan

1. Pada tahap ini, akan dilakukan pemenuhan kebutuhan adminstrasi dilakukannya pengabdian IbM serta konsolidasi dengan mitra yaitu Dinas Kesehatan Kabupaten Banyumas, bidan, dan ibu kader PKK.

2. Persiapan produk-produk pembuatan MP-ASI lokal dan perlengkapan MP-ASI.

3. Dalam pengabdian masyarakat ini menggunakan instrument kuisioner pre dan post test untuk menilai pengetahuan MPASI.

Tabel 1: Instrumen pengabdian masyarakat

\begin{tabular}{llrl}
\hline No & Instrumen & Isi Instrumen \\
\hline $\mathbf{1}$ & Kuisioner & 1. Definisi MPASI \\
& Pengatahuan & 2. Ketepatan pemberian MPASI \\
& MPASI & 3. Manfaat MPASI \\
$\mathbf{2}$ & Benner dan & 4. Cara pembuatan MPASI \\
& liflet MPASI & 2. Apa tanda bayi anda siap mendapatkan makanan padat? \\
& & 3. Aagaimana memberikan makanan pendamping ASI yang baik? \\
& & 4. Apa tips pemberian MPASI pada anak? \\
\hline
\end{tabular}


5. Apa saja mitos yang berkembang seputar pemberian makan pada bayi?

6. Ciri-ciri bayi siap mendapat MPASI

7. Bahan akanan yang sebaiknya digunakan untuk membuat MPASI

\begin{tabular}{lll}
\hline 3 & Perlangkapan & 1. Panci \\
pelatihan & 2. Kukusan \\
pembuatan & 3. Telenan \\
MPASI & 4. Saringan, pisau \\
& 5. Slow cooker \\
& 6. Nasi, labu \\
& 7. Celemek bayi \\
& 8. ASI (Air Susu Ibu) \\
& 9. Piring dan sendok bayi yg menarik \\
& 10. Buah-buahan dan sayur \\
& 11. Makanan yang mengadung protein (tempe tahu, daging, ayam, \\
& 12. Sabun dan wadah kusus untuk mencuci perlengkapan MPASI \\
\hline $\mathbf{4}$ & 1. Jenis Kelamin \\
& 2. Usia \\
& Karakteristik & 3. Agama \\
Responden & 4. Pendidikan \\
& 5. Pekerjaan \\
& 6. Lama menjadi kader \\
& 7. Masalah yang ditemui dalam kegiatan Posyandu \\
\hline
\end{tabular}

\subsection{Pendekatan Pengabdian Kepada Masyarakat :}

1. Pendekatan yang digunakan adalah model penyuluhan

2. Memberikan pelatihan kreatifitas pada kader posyandu yaitu pembuatan MP-ASI lokal dalam pemenuhan kebutuhan gizi harian anak balita.

\subsection{Partisipasi Mitra Pengabdian IbM}

Bentuk partisipasi mitra pengabdian IbM antara lain mengakomodir partisipan yang sesuai dengan kriteria inklusi dan bersedia untuk berpartisipasi pada setiap tahapan pelatihan dan pengembangan pembuatan MP-ASI lokal.

\subsection{Waktu dan Tempat Pengabdian}

Lokasi pengabdian masyarakat dilakukan di ruang zoom untuk penyuluhan dan di beberapa Posyandu untuk pelatihan MP-ASI. Pelaksanaan selama 5 hari berturut-turut.

Tabel 2. Jadwal kegiatan edukasi \& pelatihan MP-ASI

\begin{tabular}{cll}
\hline No & Tanggal & Kegiatan \\
\hline 1 & 21-23 Juli 2021 & $\begin{array}{l}\text { Koordinasi dengan Mitra yaitu Dinas Kesehatan Kabupaten, } \\
\text { kepengurusan surat dan penggalian masalah gizi balita }\end{array}$ \\
\hline 2 & 24 Juli 2021 & Persiapan instrument dan bahan untuk pelatihan MP-ASI \\
\hline 3 & 25 Juli 2021 & Penyuluhan di ruang Zoom dan pmebagian Kuesioner \\
\hline 4 & 26 Juli 2021 & Pelatihan pembuatan MP-ASI pangan lokal \\
\hline
\end{tabular}

\subsection{Pengambilan Sampel}

Sampel diambil melalui metode random sampling, dengan mengumpulkan kader posyandu balita Kabuapten Banyumas dan ibu-ibu yang memiliki bayi dan balita. Jumlah keseluruhan sampel yang hadir 
dalam kegiatan posyandu sebanyak $97 \mathrm{ibu}$-ibu. Adapun kriteria inklusi partisipan dalam pengabdian IbM ini antara lain:

1. Merupakan ibu kader Posyandu dan ibu yang memiliki bayi dan balita

2. Bersedia berpartisipasi dan menjalani seluruh rangkaian pengabdian IbM

3. Pelaksanaan penyuluhan dan pelatihan serta pengembangan diversifikasi pangan

4. Focus Group Discussion (FGD); FGD dilakukan untuk mengetahui kualitas dan hasil dari pembuatan MP-ASI lokal

\subsection{Diagram Pelaksanaan Kegiatan}

Adapun rincian tahapan kegiatan pemberdayaan masyarakat yang telah dilaksanakan tergambar melalui gambar 1 .

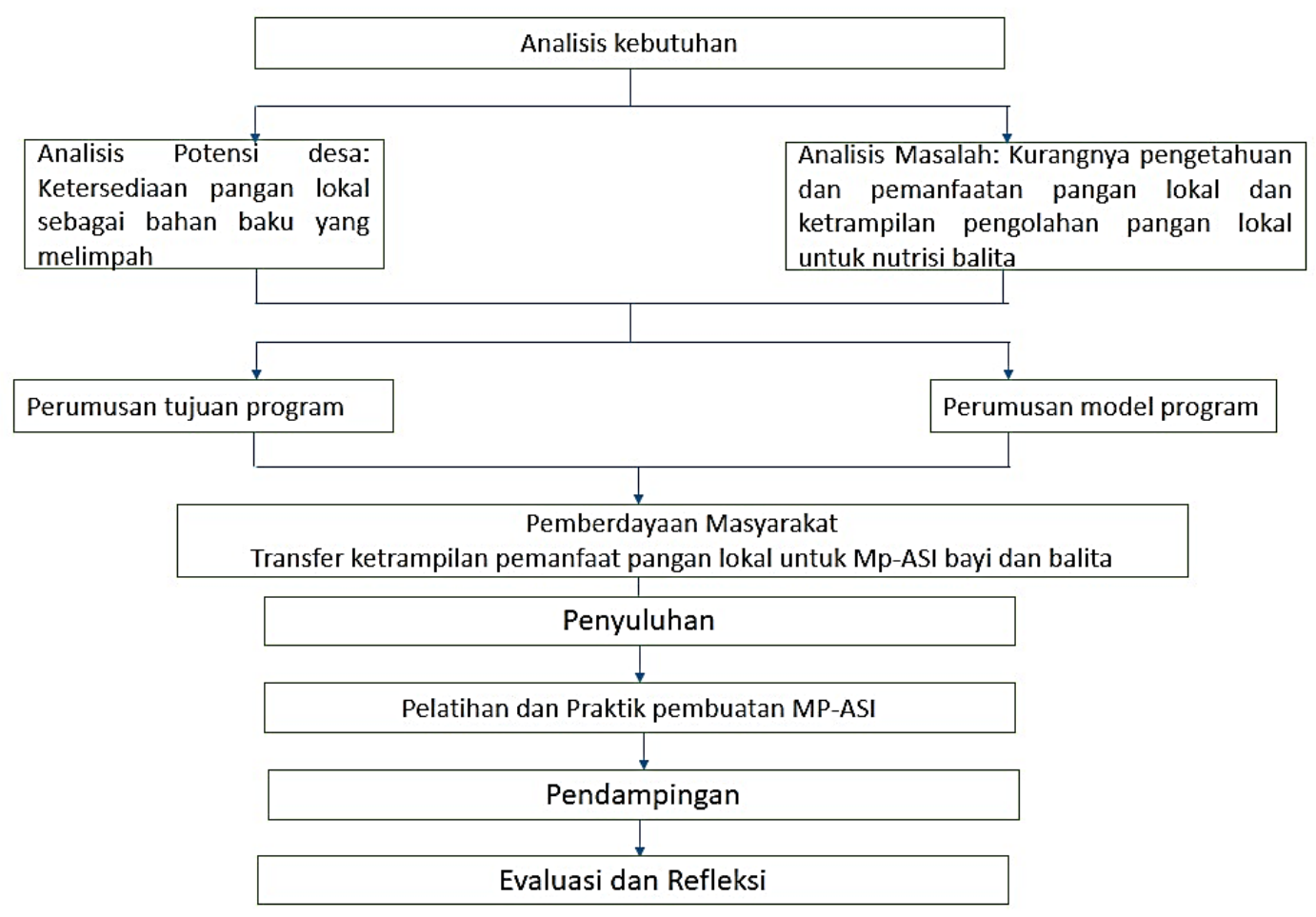

Gambar 1. Tahapan Pelaksanaan Pemberdayaan Masyarakat

\section{HASIL KEGIATAN DAN PEMBAHASAN}

Kegiatan Pelatihan MP-ASI Pangan lokal dilaksanakan pada tanggal 25 Juli 2021, dan dihadiri oleh 63 peserta kader posyandu dan kader PKK terpilih di Kabupaten Banyumas. Profil peserta pelatihan MP-ASI pangan lokal disajikan pada Tabel 3 Semua peserta adalah wanita, tidak ada peserta lelaki, dan sebagian besar berusia produktif. Sebagianaa besar peserta adalah ibu rumah tangga, berpendidikan SMA, dan telah menjadi kader $>2$ tahun.

Tabel 3. Profil Kader Posyandu dan Kader PKK Peserta Pelatihan MP-ASI Pangan Lokal

\begin{tabular}{cllcc}
\hline No & Identitas & Jenis & Jumlah & Persentase \\
\hline 1 & Jenis Kelamin & Perempuan & 63 & 100 \\
\hline \multirow{2}{*}{2} & \multirow{2}{*}{ Usia } & Laki-laki & 0 & 0 \\
\cline { 3 - 5 } & & $21-30$ & 18 & 28.57 \\
\cline { 2 - 5 } & & $31-40$ & 24 & 38.09 \\
\cline { 2 - 5 } & & $41-50$ & 15 & 23.8 \\
\hline
\end{tabular}




\begin{tabular}{|c|c|c|c|c|}
\hline & & $>50$ & 6 & 9.52 \\
\hline \multirow[t]{2}{*}{3} & \multirow[t]{2}{*}{ Agama } & Islam & 63 & 100 \\
\hline & & Kristen & 0 & 0 \\
\hline \multirow[t]{4}{*}{4} & \multirow[t]{4}{*}{ Pendidikan } & SD & 5 & 7.94 \\
\hline & & SMP & 34 & 53.97 \\
\hline & & SMA & 17 & 26.98 \\
\hline & & $\mathrm{D} 3 / \mathrm{S} 1$ & 7 & 11.11 \\
\hline \multirow[t]{3}{*}{5} & \multirow[t]{3}{*}{ Pekerjaan } & IRT & 48 & 76.19 \\
\hline & & Wiraswasta & 2 & 3.17 \\
\hline & & Karyawan & 13 & 20.63 \\
\hline \multirow[t]{2}{*}{6} & \multirow[t]{2}{*}{$\begin{array}{l}\text { Lama Menjadi } \\
\text { kader }\end{array}$} & $<2$ tahun & 24 & 38.10 \\
\hline & & $>2$ tahun & 39 & 61.90 \\
\hline \multirow[t]{6}{*}{9} & \multirow[t]{6}{*}{$\begin{array}{l}\text { Masalah yang } \\
\text { ditemui }\end{array}$} & $\begin{array}{l}\text { Masih banyak yang } \\
\text { tidak mau ke posyandu }\end{array}$ & 18 & 28.57 \\
\hline & & $\begin{array}{l}\text { Masih ditemukan balita } \\
\text { stunting }\end{array}$ & 37 & 58.73 \\
\hline & & $\begin{array}{l}\text { Tidak bisa memberi } \\
\text { penyuluhan }\end{array}$ & 6 & 9.52 \\
\hline & & $\begin{array}{l}\text { Masalah tumbuh } \\
\text { kembang }\end{array}$ & 2 & 3.17 \\
\hline & & $\begin{array}{l}\text { Pengetahuan kader } \\
\text { rendah }\end{array}$ & 1 & 1.59 \\
\hline & & $\begin{array}{l}\text { Pada saat kunjungan } \\
\text { rumah tidak diterima } \\
\text { baik }\end{array}$ & 1 & 1.59 \\
\hline
\end{tabular}

Pelatihan Gizi Seimbang dan Pengolahan MP-ASI Bahan Pangan Lokal dilaksanakan pada tanggal 26 Juli 2021, dan diikuti sebanyak 97 peserta kader posyandu, kader Pkk, serta ibu rumah tangga rawan Gizi di Kabupaten Banyumas.

Tabel 4 pengetahuan ibu tentang MP-ASI (sebelum pelatihan)

\section{Pengetahuan tentang MP-ASI pre Pelatihan}

\begin{tabular}{ccc}
\hline Baik & 7 & 7.22 \\
\hline Sedang & 17 & 17.53 \\
\hline Kurang & 73 & 75.26 \\
\hline Total & 97 & 100 \\
\hline
\end{tabular}

Masih banyak ibu yang belum mengetahui tentang MP-ASI buatan rumah /home made. Belum mengenalnyaibu kader posyandu, kader Pkk, serta ibu rumah tangga rawan Gizi tentang MP-ASI WHO Masyarakat masih khawatir memberikan bahan makanan yang bervariasi meskipun kandungan gizinya sangat dibutuhkan menjadi tujuan utama dalam pelatihan ini. Adapun setelah pelatihan dilakukan maka peneliti dan kader mengedarkan kembali kuesioner tentang MP-ASI sebagai hasil evaluasi kegiatan. Hasil evaluasi dari post pelatihan yaitu tertera pada Tabel 5. 
Tabel 5 pengetahuan ibu tentang MP-ASI (setelah pelatihan)

\begin{tabular}{ccc}
\hline $\begin{array}{c}\text { Pengetahuan tentang } \\
\text { MP-ASI pre Pelatihan }\end{array}$ & Jumlah & Presentasi \\
\hline Baik & 86 & 88.66 \\
\hline Sedang & 9 & 9.28 \\
\hline Kurang & 2 & 2.06 \\
\hline Total & 97 & 100 \\
\hline
\end{tabular}

Setelah mengikuti pelatihan Gizi Seimbang, sejumlah 80 persen peserta meningkat wawasan Gizi Seimbang. Selain itu, pelatihan membuat produk MP ASI bergizi dan bernahan pangan lokal berlangsung lancar dan semua ibu peserta ikut membuat produk MP-ASI. Produk MP-ASI yang dibuat diwajibkan untuk diberikan kepada anak baduta yang kurang gizi dan diamati pertambahan berat badannya pada selama satu bulan. Peserta mengusulkan untuk dapat mengikuti pelatihan pengolahan MP-ASI pada kesempatan lain.
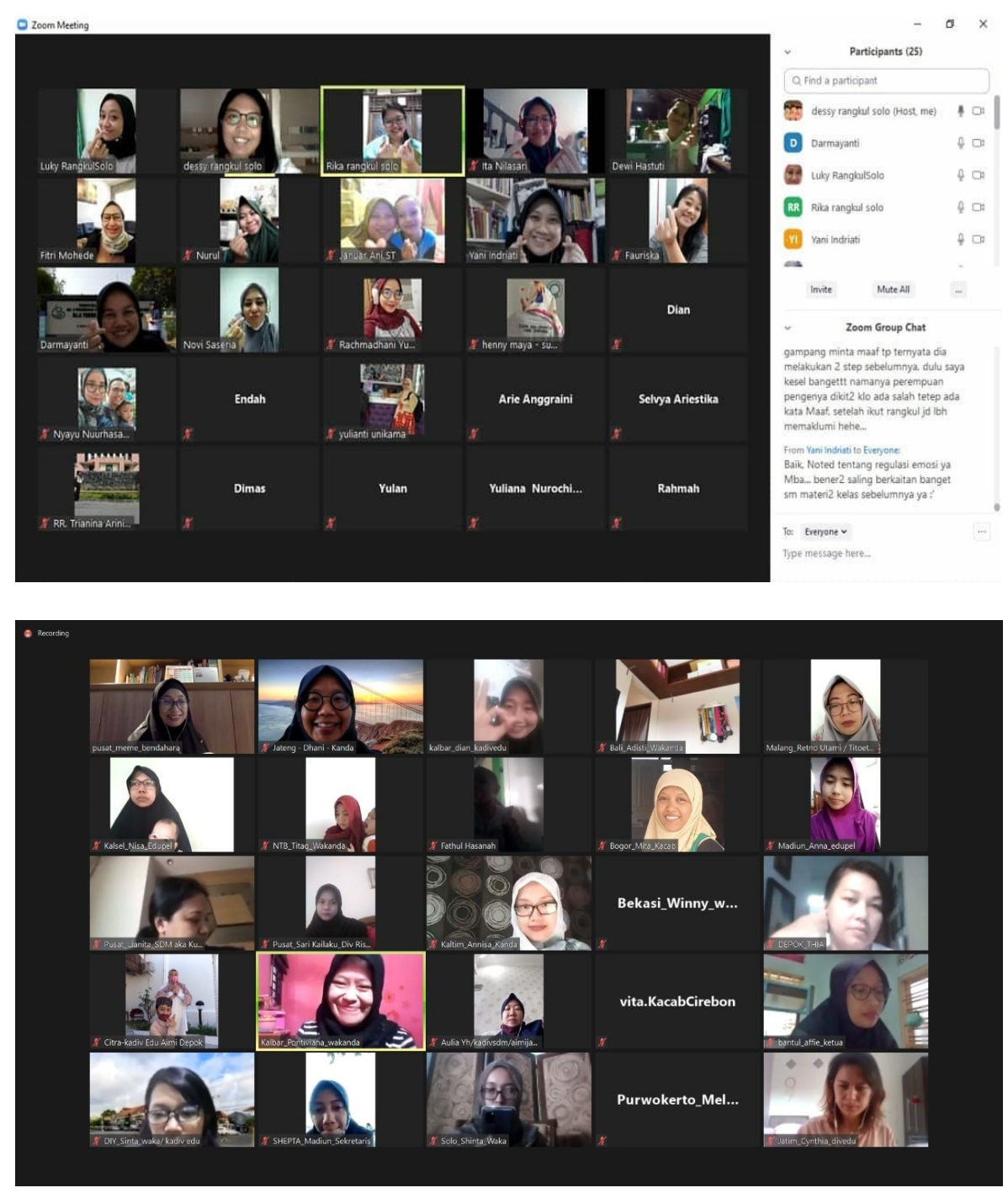

Gambar 2. Kegiatan Zoom Online dengan kader 

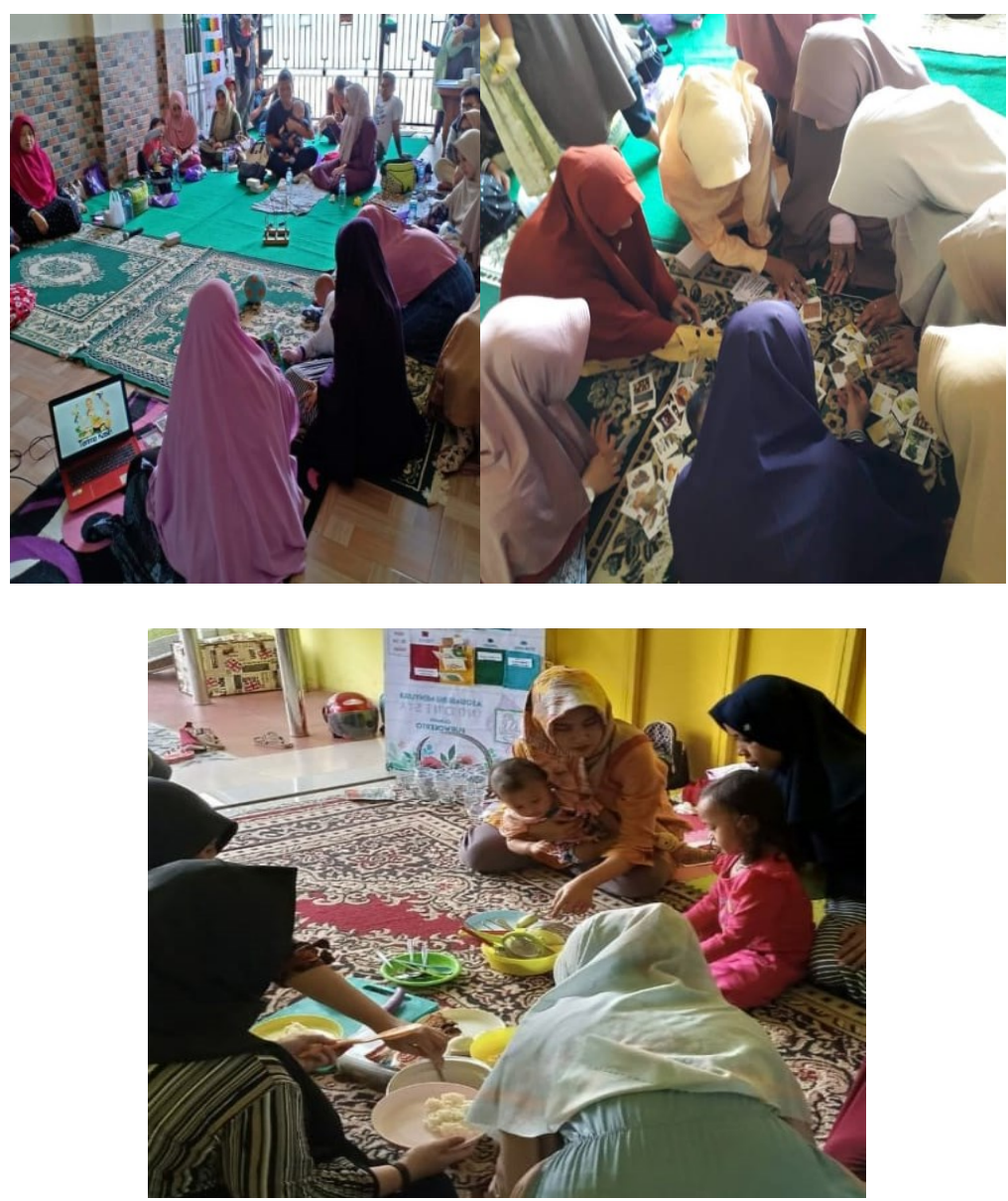

Gambar 3. Kegiatan pelatihan pembuatan MP-ASI pangan lokalSIMPULAN

\section{SIMPULAN DAN SARAN}

Kegiatan Pengabdian pada Masyarakat yang berhasil dilaksanakan terdiri kegiatan Pelatihan MPASI Pangan Bergizi Berbahan Lokal pada tanggal 25-26 Juli 2021 dengan 63 peserta kader posyandu dan PKK, dan 34 ibu rumah tangga yang memiliki bayi dan balita dan dan keluarga rawan gizi. Jumlah total yang mengikuti pelatihan sebanyak 97 peserta. Melalui kegiatan Pelatihan Pangan Bergizi yang dilksanakan dengan metoda Food Game, kader posyandu dan kader PKK, ibu rumah tangga yang memiliki bayi dan balita dan keluarga rawan gizi meningkat wawasan pangan dan gizi yang diperlukan pada kegiatan penyuluhan gizi bagi ibu baduta dan balita yang BGM. Pengetahuan sumber pangan bergizi tersebut menjadi modal bagi dirinya dalam melakukan tugas penyuluhan gizi di meja IV kegiatan posyandu setiap bulan.

Kegiatan Pelatihan Gizi Kehamilan meningkatkan wawasan bidan peserta pelatihan. Pembekalan pengetahuan tentang Gizi dan Gizi 1000 hari pertama kehidupan, dirasakan sangat bermanfaat dalam memotivasi peserta. Demikian juga dengan pembekalan pangan sumber zat gizi, peserta antusias bertanya terkait pangan dan kesehatan.

Pada kegiatan Pelatihan Gizi Seimbang dan Membuat MP-ASI, peserta melakukan proses membuat produk MP-ASI pangan lokal. Bahan bergizi yang ditambahkan adalah tepung kacang-kacangan local seperti kacang merah, kacang hijau, dan kacang tolo, serta protein hewani yang mudah didapat dan dimaksudkan untuk menambah asupan protein untuk anak balita kurang gizi dan stunting.

Semua kegiatan pelatihan yang telah dilaksanakan dinilai bermanfaat bagi kader posyandu dan kader gizi, bidan, serta ibu rumah tangga rawan gizi yang mengikuti pelatihan secara serius. Keseriusan 
terbukti dari banyak pertanyaan yang disampaikan pada saat pelatihan. Selain itu, ada permintaan untuk diadakan pelatihan lagi di masa mendatang..

\section{DAFTAR PUSTAKA}

AMAR, M. I., \& NASRULLAH, N. (2020). Penyuluhan Dan Pembuatan Mp-Asi Lokal Dengan Bahan Dasar Bmc (Bahan Makanan Campuran) Untuk Balita Pada Kader Posyandu Di Wilayah Kerja Puskesmas Cikulur Kabupaten Lebak 2019. Diseminasi: Jurnal Pengabdian Kepada Masyarakat, 2(2), 58-63. https://doi.org/10.33830/diseminasiabdimas.v2i2.1033

Aryastami, N. K. (2017). Kajian Kebijakan dan Penanggulangan Masalah Gizi Stunting di Indonesia. Buletin Penelitian Kesehatan, 45(4), 233-240. https://doi.org/10.22435/bpk.v45i4.7465.233-240

BAPENAS. (2011). Rencana aksi PAngan ANsional Pangan dan Gizi 2011-2015. September.

BPS. (2020). Profil Kesehatan Ibu Dan Anak 2020. Badan Pusat Statistik, 53(9), 111-133.

Dinas Kesehatan Provinsi Jawa Tengah. (2019). Profil Kesehatan Provinsi Jateng Tahun 2019. Dinas Kesehatan Provinsi Jawa Tengah, 3511351(24), 273-275.

Hendricks, M. (2001). Management of the child with serious infection or severe malnutrition. South African Medical Journal, 91(10 I), 832.

Kemenkes. (2018). Riset Kesehatan Dasar Tahun 2018.

Kemenkes. (2019). Profil Kesehatan Indonesia Tahun 2020.

Kemenkes 2018. (n.d.). Situasi Balita Pendek (Stunting) di Indonesia, 2018.

Kemenkes RI. (2011). KEPMENKES RI Tentang Standar Antropometri Penilaian Status Gizi Anak. In Jornal de Pediatria (Vol. 95, Issue 4, p. 41).

Margaretta, S. S. (2019). Edukasi dan Pelatihan Pembuatan Makanan Pendamping ASI (MP-ASI) di Posyandu Desa Sonorejo, Kecamatan Grogol, Kabupaten Kediri. Journal of Chemical Information and Modeling, 1(2), 248-252.

Mohammed, S. H., Larijani, B., \& Esmaillzadeh, A. (2019). Concurrent anemia and stunting in young children: Prevalence, dietary and non-dietary associated factors. Nutrition Journal, 18(1), 1-10. https://doi.org/10.1186/s12937-019-0436-4

Report, G. N. (2020). Global Nutrition Report. In The Global Nutrition Report's Independent Expert Group.

Sudaryati, E., Nasution, E., \& Yustina, I. (2017). Stunting and Anemia in Infants Among Breastfeeding Mothers in Binjai City. 1(PHICo 2016), 331-336. https://doi.org/10.2991/phico-16.2017.14

WHO. (2003). Global Strategy for Infant and Young Child Feeding. Fifthy-Fourth World Health Assembly, $1,8$. 